\title{
The overlap phenotype: the (missing) link between asthma and COPD
}

\author{
Barbara Piras ${ }^{1}$ and Marc Miravitlles ${ }^{2^{*}}$
}

The definition of chronic obstructive pulmonary disease (COPD) as a preventable and treatable condition characterized by a not completely reversible chronic airflow obstruction [1] is so broad and imprecise that many different types of patients with distinct clinical characteristics, prognosis and response to treatments may fit in. These different types are now described as "clinical phenotypes" and the interest in their definition and characterisation is growing [2]. Among these phenotypes, the so-called overlap of syndromes with airflow obstruction is usually poorly considered [3].

In a first step of phenotyping, a COPD patient can potentially be classified as a predominant parenchymal destructive or predominant airflow limitation phenotype by using a few clinical, radiological and functional findings [4]. However, when a patient presents characteristics and symptoms of two or more respiratory diseases at the same time, this is described as an overlap syndrome. In particular, the asthma-COPD overlap phenotype has been described as symptoms of increased variability of airflow in association with an incompletely reversible airflow obstruction [5]. From a clinical point of view it usually corresponds to individuals diagnosed with asthma before the age of 40 who, at an older age, fulfil the criteria for COPD [6]. Recent estimations of its prevalence report that about $13-20 \%$ of subjects with COPD have the overlap phenotype [6,7], with an increasing trend in the elderly population (up to $50 \%$ in those aged over 70 years) [7]. Since they have been systematically excluded from both COPD and asthma pharmacological clinical trials as not being "pure" subjects, it is clear that we cannot really know the response to pharmacological treatment of a significant number of patients with COPD.

Increased reversibility is one of the key differential aspects of individuals with the overlap asthma-COPD phenotype. Reversibility in COPD is not only possible

\footnotetext{
* Correspondence: marcm@separ.es

${ }^{2}$ Institut d'Investigacions Biomèdiques August Pi i Sunyer (IDIBAPS), Hospital Clínic, Ciber de Enfermedades Respiratorias (CIBERES), Villarroel 170, 08036, Barcelona, Spain

Full list of author information is available at the end of the article
}

but it is also not so infrequent: indeed, significant reversibility in COPD is observed frequently in everyday clinical practice and in a series of patients included in the newly designed clinical trials [8]. Over one half to almost two-thirds of the patients with moderate-to-very-severe COPD participating in the large clinical trial UPLIFT met the most commonly used criteria for acute bronchodilator responsiveness [9]. In a recent study of COPD patients without a prior history of asthma, $44 \%$ of the subjects showed a positive bronchodilator test with an inverse correlation between bronchodilator reversibility and the GOLD severity stages [10].

Reversibility, however, has not been considered to be a reliable parameter to diagnose or classify patients; the reason being that a patient may be reversible or irreversible in different determinations at different time points [11]. This is a consequence of dichotomising a continuous variable as positive or negative. In fact, this approach could be valid for epidemiologic studies but should never be used to guide clinical decisions in an individual patient. Reversibility in clinical practice must be considered as a continuous variable, and therapeutic decisions should be made according to the magnitude of the change. One example will help to explain this concept: a patient with a reversibility of $11.8 \%$ in forced expiratory volume in the $1^{\text {st }}$ second $\left(\mathrm{FEV}_{1}\right)$ has the same kind of reversibility as a patient with an increase of $12.2 \%$, despite the first being negative and the latter positive. In contrast, the latter patient (the one with an increase in $\mathrm{FEV}_{1}$ of $12.2 \%$ ) may have a different response to treatment compared to a patient with a reversibility of $45 \%$, despite the fact of both being positive.

Why is it so important to identify the overlap phenotype? From a clinical point of view, it is composed of COPD patients with increased reversibility and/or of smoker asthmatics with fixed airflow obstruction. Are they just the same patients with different names? Probably yes. In COPD, the positive bronchodilator response is associated with an enhanced eosinophilic inflammation in the airways in contrast to the predominance of neutrophils in irreversible 
COPD [12]. Similarly, the inflammation in asthma is associated with CD4+ T lymphocytes and eosinophils, and it is very responsive to corticosteroids. Conversely, neutrophilic inflammation has been linked to airflow obstruction severity both in asthma and COPD. Severe asthmatics, those with fixed airflow obstruction or those with a history of smoking, exhibit higher numbers of neutrophils in bronchoalveolar lavage fluid and biopsies [13-15]. Sputum neutrophils in stable COPD are negatively correlated with the $\mathrm{FEV}_{1}$ percent predicted and accelerated $\mathrm{FEV}_{1}$ decline, especially in patients without bronchodilator reversibility $[15,16]$. Neutrophilic and eosinophilic inflammations demonstrate different responses to corticosteroid treatment. These observations suggest that patients with COPD and the overlap phenotype may have some degree of eosinophilic inflammation which is more responsive to corticosteroids and has a somewhat better prognosis than patients with irreversible airway obstruction. In addition, reversible patients with COPD also present more eosinophils in sputum and higher concentrations of exhaled nitric oxide (NO) $[11,15,17,18]$.

During exacerbations the airway inflammation becomes even more intense, with recruitment of neutrophils and eosinophils and increased CD4+ lymphocytes in the bronchial mucosa $[19,20]$. Studies in bronchial biopsies of exacerbated patients with mild to moderate COPD have shown a 30-fold increase in the total number of eosinophils and a 3-fold increase of neutrophils in their bronchial mucosa [21]. This increase in eosinophils during exacerbations may explain, at least in part, the clinical improvement associated with the use of corticosteroids in exacerbations of COPD [22]. Interestingly, patients with the overlap phenotype are also more likely to be frequent exacerbators (defined as the presence of two or more exacerbations per year), to have a worse quality of life, more respiratory symptoms $[6,15]$ and to consume from 2 to 6 -fold the resources used by asthma or COPD patients [23]. In addition, an increased mortality has been observed in COPD patients with peripheral eosinophilia [24].

How may all these findings affect the management of our patients? It is clear that not all COPD patients have the same clinical and inflammatory characteristics and not all types of patients are represented in clinical trials. The GOLD guidelines suggest adding inhaled corticosteroids (ICs) to the treatment of patients with severe or exacerbated COPD [1]. This recommendation does not take into account the possible responsiveness to ICs. Neutrophilic inflammation present in most patients with COPD, irrespective of the number of exacerbations, does not respond to ICs [25]. On the contrary, patients with a component of eosinophilic inflammation show a significant improvement in bronchial inflammation and, more interestingly, a clinical improvement, even in mild to moderate stages of COPD
$[9,26,27]$. In particular, one randomised trial demonstrated that prescribing ICs according to the intensity of eosinophilic inflammation in sputum was significantly superior in preventing exacerbations compared to the prescription of ICs according to guidelines [28]. This demonstrates that guidelines must be improved with recognition of personalised treatment and patterns of therapy guided by phenotypes instead of severity of airflow obstruction [29,30]. Nowadays, only the Canadian and the Japanese guidelines consider these particular characteristics of patients with COPD. The Canadian guidelines specify that: "if the asthma component (in COPD) is prominent, earlier introduction of ICs may be justified" [31]; the Japanese guideline dedicates a chapter to "Treatment of COPD complicated by asthma" [32]. The future Spanish guidelines of COPD will direct treatment according to phenotypes, and the overlap phenotype will be one of them [33].

We should not forget that COPD patients are mostly elderly, with comorbidities that require numerous drugs; therefore, avoiding the use of unnecessary medications, which may be associated with frequent and serious side effects and increased costs, must be mandatory.

Obviously, the characterization of phenotypes will require more time to be spent for the clinical evaluation of patients, but with simple investigations we should be able to diagnose the overlap phenotype in COPD [34]. Recently, by consensus a group of experts established the diagnostic criteria for the overlap phenotype. To be diagnosed with an overlap phenotype, a patient must fulfill 2 major criteria or one major and two minor among the following: A) Major criteria: very positive bronchodilator response $\left(>400 \mathrm{ml}\right.$ and $>15 \%$ in $\left.\mathrm{FEV}_{1}\right)$, sputum eosinophilia or previous diagnosis of asthma. B) Minor criteria: increased total serum IgE, previous history of atopy or positive bronchodilator test $(>200 \mathrm{~mL}$ and $>12 \%$ in $\mathrm{FEV}_{1}$ ) on at least two occasions [35]. These are quite restrictive criteria and a very conservative approach until we have more evidence from large clinical trials about characterization and differential response of the overlap phenotype. Whether you believe in the hypothesis of asthma and COPD as two expressions of the same disease (the Dutch hypothesis) or not, patients with overlap syndrome are surely different from both those with COPD and those with asthma. In many aspects they share characteristics of the two diseases, but with significant differences in clinical features such as age, lung function and cardiovascular comorbidity [36] and, even more importantly, they respond differently to existing anti-inflammatory therapies.

It is time to recognize that COPD is not a single easily treatable disease, but that it has truly different clinical, radiological and functional aspects that can mix together in distinct phenotypes, and treatment has to be tailored to the 
patient's characteristics beyond simply the degree of airflow obstruction [37].

\section{Author details}

'Institute of Respiratory Diseases and TB, University of Sassari, 21 Università Square, 07100, Sassari, Italy. ${ }^{2}$ Institut d'Investigacions Biomèdiques August Pi i Sunyer (IDIBAPS), Hospital Clínic, Ciber de Enfermedades Respiratorias (CIBERES), Villarroel 170, 08036, Barcelona, Spain.

Received: 23 May 2012 Accepted: 20 June 2012

Published: 20 June 2012

\section{References}

1. Global Initiative for Chronic Obstructive Lung Disease (GOLD): Global strategy for the diagnosis, management, and prevention of chronic obstructive pulmonary disease (Update 2010) www.goldcopd.com.

2. Han MK, Agustí A, Calverley PM, Celli BR, Criner G, Curtis JL, Fabbri LM, Goldin JG, Jones PW, Macnee W, Make BJ, Rabe KF, Rennard SI, Sciurba FC, Silverman EK, Vestbo J, Washko GR, Wouters EF, Martinez FJ: Chronic obstructive pulmonary disease phenotypes: the future of COPD. Am J Respir Crit Care Med 2010, 182:598-604.

3. Wardlaw AJ, Silverman M, Siva R, Pavord ID, Green R: Multi-dimensional phenotyping: towards a new taxonomy for airway disease. Clin Exp Allergy 2005, 35:1254-1262.

4. Pistolesi M, Camiciottoli G, Paoletti M, Marmai C, Lavorini F, Meoni E, Marchesi C, Giuntini C: Identification of a predominant COPD phenotype in clinical practice. Respir Med 2008, 102:367-376.

5. Gibson PG, Simpson JL: The overlap syndrome of asthma and COPD what are its features and how important is it? Thorax 2009, 64:728-735.

6. Hardin M, Silverman EK, Barr RG, Hansel NH, Schroeder, Make BJ, Crapo JD, Hersh CP: OPDGene Investigators. The clinical features of the overlap between COPD and asthma. Respir Res 2011, 12:127.

7. Soriano JB, Davis KJ, Coleman B, Visick G, Mannino D, Pride NB: The proportional Venn diagram of obstructive lung disease: two approximations from the United States and the United Kingdom. Chest 2003, 124:474-481.

8. Welte T, Miravitlles M, Hernandez P, Eriksson G, Peterson S, Polanowski T, Kessler R: Efficacy and tolerability of budesonide/formoterol added to tiotropium in patients with chronic obstructive pulmonary disease. Am J Respir Crit Care Med 2009, 180:741-750.

9. Tashkin DP, Celli B, Decramer M, Liu D, Burkhart D, Cassino C, Kesten S: Bronchodilator responsiveness in patients with COPD. Eur Respir J 2008, 31:742-750.

10. Bleecker ER, Emmett A, Crater G, Knobil K, Kalberg C: Lung function and symptom improvement with fluticasone propionate/salmeterol and ipratropium bromide/albuterol in COPD: response by beta-agonist reversibility. Pulm Pharmacol Ther 2008, 21:682-688.

11. Calverley PM, Burge PS, Spencer S, Anderson JA, Jones PW: Bronchodilator reversibility testing in chronic obstructive pulmonary disease. Thorax 2003, 58:659-664.

12. Papi A, Romagnoli M, Baraldo S, Braccioni F, Guzzinati I, Saetta M, Ciaccia A, Fabbri LM: Partial reversibility of airflow limitation and increased exhaled $\mathrm{NO}$ and sputum eosinophilia in chronic obstructive pulmonary disease. Am J Respir Crit Care Med 2000, 162:1773-1777.

13. Wenzel SE, Szefler SJ, Leung DY, Sloan SI, Rex MD, Martin RJ: Bronchoscopic evaluation of severe asthma. Persistent inflammation associated with high dose glucocorticoids. Am J Respir Crit Care Med 1997, 156:737-743.

14. Louis R, Lau LC, Bron AO, Roldaan AC, Radermecker M, Djukanović R: The relationship between airways inflammation and asthma severity. Am J Respir Crit Care Med 2000, 161:9-16.

15. Contoli M, Baraldo S, Marku B, Casolari P, Marwick JA, Turato G, Romagnoli M, Caramori G, Saetta M, Fabbri LM, Papi A: Fixed airflow obstruction due to asthma or chronic obstructive pulmonary disease: 5-year follow-up. $J$ Allergy Clin Immunol 2010, 125:830-837.

16. Perng DW, Huang HY, Chen HM, Lee YC, Perng RP: Characteristics of airway inflammation and bronchodilator reversibility in COPD: a potential guide to treatment. Chest 2004, 126:375-381.

17. Kunisaki KM, Rice KL, Janoff EN, Rector TS, Niewoehner DE: Exhaled nitric oxide, systemic inflammation, and the spirometric response to inhaled fluticasone propionate in severe chronic obstructive pulmonary disease: a prospective study. Ther Adv Respir Dis 2008, 2:55-64.

18. Foschino Barbaro MP, Carpagnano GE, Spanevello A, Cagnazzo MG, Barnes PJ: Inflammation, oxidative stress and systemic effects in mild chronic obstructive pulmonary disease. Int I Immunopathol Pharmacol 2007, 20:753-763.

19. Saetta M, Baraldo S, Zuin R: Neutrophil chemokines in severe exacerbations of chronic obstructive pulmonary disease: fatal chemo-attraction? Am J Respir Crit Care Med 2003, 168:911-913.

20. Zhu J, Qiu YS, Majumdar S, Gamble E, Matin D, Turato G, Fabbri LM, Barnes N, Saetta M, Jeffery PK: Exacerbations of bronchitis: bronchial eosinophilia and gene expression for interleukin-4, interleukin-5, and eosinophil chemoattractants. Am J Respir Crit Care Med 2001, 164:109-116.

21. Saetta M, Di Stefano A, Maestrelli P, Turato G, Ruggieri MP, Roggeri A, Calcagni P, Mapp CE, Ciaccia A, Fabbri LM: Airway eosinophilia in chronic bronchitis during exacerbations. Am J Respir Crit Care Med 1994, 150:1646-1652.

22. Niewoehner DE, Erbland ML, Deupree RH, Collins D, Gross NJ, Light RW, Anderson P, Morgan NA: Effect of systemic glucocorticoids on exacerbations of chronic obstructive pulmonary disease. Department of Veterans Affairs Cooperative Study Group. N Engl J Med 1999, 340:1941-1947.

23. Shaya FT, Dongyi D, Akazawa MO, Blanchette CM, Wang J, Mapel DW, Dalal A, Scharf SM: Burden of concomitant asthma and COPD in a Medicaid population. Chest 2008, 134:14-19.

24. Hospers JJ, Schouten JP, Weiss ST, Rijcken B, Postma DS: Asthma attacks with eosinophilia predict mortality from chronic obstructive pulmonary disease in a general population sample. Am J Respir Crit Care Med 1999, 160:1869-1874.

25. Miravitlles M: Arguments in favor of inhaled corticosteroids in COPD by phenotype instead of by severity. Arch Bronconeumol 2011, 47:271-273.

26. Brightling CE, Monteiro W, Ward R, Parker D, Morgan MD, Wardlaw AJ, Pavord ID: Sputum eosinophilia and short-term response to prednisolone in chronic obstructive pulmonary disease: a randomised controlled trial. Lancet 2000, 356:1480-1485.

27. Brightling CE, McKenna S, Hargadon B, Birring S, Green R, Siva R, Berry M, Parker D, Monteiro W, Pavord ID, Bradding P: Sputum eosinophilia and the short term response to inhaled mometasone in chronic obstructive pulmonary disease. Thorax 2005, 60:193-198.

28. Siva R, Green RH, Brightling CE, Shelley M, Hargadon B, McKenna S, Monteiro W, Berry M, Parker D, Wardlaw AJ, Pavord ID: Eosinophilic airway inflammation and exacerbations of COPD: a randomised controlled trial. Eur Respir J 2007, 29:906-913.

29. Anderson D, MacNee W: Targeted treatment in COPD: a multi-system approach for a multi-system disease. Int I Chron Obstruct Pulmon Dis 2009, 4:321-335.

30. Miravitlles M: Individually-tailored treatment of chronic obstructive pulmonary disease: a proposed change. Arch Bronconeumol 2009, 45(Suppl 5):27-34.

31. O'Donnell DE, Aaron S, Bourbeau J, Hernandez P, Marciniuk DD, Balter M, Ford G, Gervais A, Goldstein R, Hodder R, Kaplan A, Keenan S, Lacasse Y, Maltais F, Road J, Rocker G, Sin D, Sinuff T, Voduc N: Canadian Thoracic Society recommendations for management of chronic obstructive pulmonary disease - 2007 update. Can Respir 2007, 14(Suppl B):5B-32B.

32. Nagai A, Aizawa H, Aoshiba K, Asano K, Hirata K, Ichinose M, Ishihara H, Iwanaga T, Kawane H, Kida K, Kimura H, Kohno S, Kubo K, Kuriyama T, Nagase T, Nishimura M, Ohta K, Onuki T, Seyama K, Sakai F, Shioya T, Shirakusa T, Tatsumi K, Matsuse H, Mishima M, Ueki J, Yamaya M: Guidelines for the diagnosis and treatment of COPD. Tokyo (Japan): The Japanese Respiratory Society; 2009. http://www.jrs.or.jp/home/uploads/photos/765.pdf.

33. Miravitlles M, Calle M, Soler-Cataluña JJ: Clinical phenotypes of COPD. Identification, definition and implications for guidelines. Arch Bronconeumol 2012, 48:86-98.

34. Miravitlles M: The overlap syndrome between asthma and COPD: implications for management. Hot Topics Respir Med 2011, 16:15-20.

35. Soler-Cataluña JJ, Cosío B, Izquierdo JL, López-Campos JL, Marín JM, Agüero R, Baloira A, Carrizo S, Esteban C, Galdiz JB, Gonzalez MC, Miravitlles M, Monsó E, Montemayor T, Morera J, Ortega F, Peces-Barba G, Puente L, Rodriguez JM, Sala E, Sauleda J, Soriano JB, Vieajo JL: Consensus 
document on overlap asthma-COPD phenotype. Arch Bronconeumol, in press.

36. Kauppi $P$, Kupiainen $H$, Lindqvist $A$, Tammilehto L, Kilpeläinen $M$, Kinnula VL, Haahtela T, Laitinen T: Overlap syndrome of asthma and COPD predicts low quality of life. J Asthma 2011, 48:279-285.

37. Grupo de Trabajo de GESEPOC: Moving towards a new focus on COPD. The Spanish COPD guidelines (GESEPOC). Arch Bronconeumol 2011, 47:379-381.

doi:10.1186/2049-6958-7-8

Cite this article as: Piras and Miravitlles: The overlap phenotype: the (missing) link between asthma and COPD. Multidisciplinary Respiratory Medicine 2012 7:8.

\section{Submit your next manuscript to BioMed Central and take full advantage of:}

- Convenient online submission

- Thorough peer review

- No space constraints or color figure charges

- Immediate publication on acceptance

- Inclusion in PubMed, CAS, Scopus and Google Scholar

- Research which is freely available for redistribution 